\title{
Effects of polymorphisms in APOB, APOE, HSD11 1 , PLIN4, and ADIPOQ genes on lipid profile and anthropometric variables related to obesity in children and adolescents
}

\author{
Caroline C. Gasparin ${ }^{1}$, Neiva Leite ${ }^{2}$, Luciane V. Tureck ${ }^{1}$, Ricardo L.R. Souza ${ }^{1}$ iD , Gerusa E. Milano-Gai ${ }^{2}$, \\ Larissa R. Silva $^{2}$, Wendell A. Lopes ${ }^{2}$ and Lupe Furtado-Alle ${ }^{1}$ iD \\ ${ }^{1}$ Laboratório de Polimorfismos e Ligação, Departamento de Genética, Universidade Federal do Paraná \\ (UFPR) Curitiba, PR, Brazil. \\ ${ }^{2}$ Departamento de Educação Física, Universidade Federal do Paraná (UFPR) Curitiba, PR, Brazil.
}

\begin{abstract}
Genes can influence lipid profile and anthropometric variables related to obesity. The present study aimed to verify if variants of the APOE, APOB, ADIPOQ, HSD11 1 , and PLIN4 genes are associated with lipid levels or anthropometric variables in a sample comprised of 393 Euro-Brazilian children and adolescents. DNA was genotyped by TaqMan allelic discrimination assay. The $\varepsilon 4$ and $\varepsilon 2$ alleles of the $A P O E$ gene were associated respectively with lower high-density lipoprotein cholesterol (HDL-C) and low-density lipoprotein cholesterol (LDL-C) levels $(p=0.015$ and $p=0.012$, respectively), while the $\varepsilon 3$ allele was associated with higher abdominal circumference $(p=0.0416)$ and excess weight ( $p=0.0001)$. The $\mathrm{G}$ allele ( $\mathrm{rs} 846910$ ) of the HSD11 1 gene was also associated with excess weight $(p=0.039)$. No other association was found. Our results indicate that the $\varepsilon 4$ and $\varepsilon 2$ alleles could contribute to lower HDL-C and LDL-C levels, respectively, furthermore, the $\varepsilon 3$ allele and the G allele (rs846910) of HSD11ß1 gene may be risk factors for excess of weight. These findings are very important because we observed that some genetic variants influence the lipid profile and anthropometric variables early in life.
\end{abstract}

Keywords: PLIN4 gene, APOB gene, ADIPOQ gene, HSD11 11 gene, APOE gene.

Received: June 27, 2017; Accepted: March 7, 2016.

\section{Introduction}

Dyslipidemia is closely related to the development of cardiovascular and cerebrovascular diseases, such as atherosclerosis, acute myocardial infarction, ischemic heart disease, and cerebrovascular accident, and therefore of great relevance for public health (ANVISA, 2011; Maria et al. 2011). It is estimated that $53 \%$ of American adults have lipid abnormalities (Tóth et al., 2012). In Brazil, according to Alcântara Neto et al. (2012), the prevalence of dyslipidemia among children and adolescents enrolled in the public school system was $25.5 \%$. They also found a positive association between dyslipidemia and overweight (Alcântara Neto et al., 2012). Worldwide, in 2015, the number of overweight children under five years old had been estimated at more than 42 million (WHO, 2016).

Dyslipidemias, as well as obesity, are mainly multifactorial traits, influenced by the environment, genetic factors, and life habits. Polymorphisms of the $A P O B, A P O E$, $A D I P O Q, P L I N 4$, and HSDI1 11 genes are important ex-

Send correspondence to Lupe Furtado Alle. Polymorphisms and Linkage Laboratory, Department of Genetics, Federal University of Paraná (UFPR), Curitiba, PR, Brazil. E-mail: lupealle @gmail.com. amples of genetic causes associated with dyslipidemias and obesity. The genetic variants selected for this study seem to have functional effects, being involved in lipid metabolism and features related to obesity (Innerarity et al., 1987; Soria et al., 1989; Myant, 1993; Arita et al., 1999; Foley, 2005; Greenow et al., 2005; Heeren et al., 2006; Lara-Castro et al., 2007; Gambineri et al., 2011; Richardson et al., 2011).

The APOE glycoprotein plays an important role in metabolism, transport, and redistribution of molecules that carry cholesterol and other lipids (Poirier, 2005). It is encoded by a gene of the same name (19q13.2) and mediates the uptake of chylomicrons, very low-density lipoprotein (VLDL) and intermediate density lipoprotein (IDL) (Mahley, 1988; Weisgraber et al., 1981). The $\varepsilon 2, \varepsilon 3$, and $\varepsilon 4$ alleles (rs7412: NM_000041.3:c.526C > T and rs429358: NM_000041.3:c.388T > C) are combined in two important positions (Weisgraber et al., 1981), producing therefore the three APOE major isoforms E2 (Cys 112, Cys 158), E3 (112 Cys, Arg 158), and E4 (Arg 112, Arg 158) (Foley 2005; Greenow et al., 2005; Heeren et al., 2006). ApoB100 is encoded by the $A P O B$ gene (2p24.1) and it is present on the surface of LDLs (Blackhart et al., 1986; Innerarity et al., 1987). The R3500Q mutation (rs5742904: 
NM_000384.2:c.10580G > A) leads to diminished affinity for its receptor (Innerarity et al., 1987; Soria et al., 1989; Myant, 1993).

PLIN4 (19p13.3; Ensembl 2015) participates in the Perilipin/ADRP/TIP47 (PAT) family of lipid storage droplet (LSD) proteins and appears to be involved in the storage of lipids in adipocytes (Brasaemle, 2007). The rs8887 (NM_001080400.1:c.*2270A > G) polymorphism is situated in the 3'UTR region of PLIN4 gene. The less frequent allele of this site may induce a reduction of up to $20 \%$ in the PLIN4 level due to the creation of a miR-522 binding site in the 3'UTR region of the gene (Richardson et al., 2011).

The human gene encoding adiponectin, $A D I P O Q$ gene (3q27), is the most expressed gene in adipose tissue (Maeda et al., 1996). Obesity, and in particular the accumulation of abdominal visceral fat, as well as type 2 diabetes mellitus, coronary disease, and arterial hypertension are accompanied by a reduction of serum adiponectin (Arita $e t$ al., 1999; Lara-Castro et al., 2007). The SNP of the ADIPOQ gene was rs1501299: NM_001177800.1:c.214+62G $>$ T.

The HDS11ß1 gene (1q32.2; Ensembl, 2015) encodes the enzyme hydroxysteroid dehydrogenase type 1 (11ß-HSD1), which is responsible for the conversion of inactive to active cortisol, in addition to regulating the interaction of cortisol with glucocorticoid receptors (Bujalska et $a l ., 1997)$. Transgenic rats that overexpress this enzyme in adipose tissue develop visceral obesity, insulin resistance, hyperglycemia, and hyperlipidemia (Masuzaki et al., 2001). Among its polymorphisms are rs 846910 (NM_001206741.1:c.-48-2986A > G), which corresponds to a non-coding region SNP of the HSD11 1 gene, and rs12086634 (NM_001206741.1:c.332-29T > G), which occurs in an enhancer region in intron 3 (Gambineri et al., 2011).

Hence, the aim of the present study was to investigate possible influences of the PLIN4 (rs8887), APOB (rs5742904), ADIPOQ (rs1501299), HSD11ß1 (rs848910 and rs12086634), and $A P O E$ (rs7412 and rs429358; alleles $\varepsilon 2, \varepsilon 3$, and $\varepsilon 4$ ) genes on lipid and glucose levels, abdominal circumference, and obesity in a sample of children and adolescents from a population in southern Brazil.

\section{Subjects and Methods}

\section{Subjects}

The sample was comprised of 393 Euro-Brazilians (13.54 \pm 0.095 years old) living in Curitiba, PR, of which 143 were eutrophic and 250 overweight. Of these 393 individuals, 128 were girls $(21.09 \%$ eutrophic and $78.91 \%$ overweight) and 265 were boys (43.94\% eutrophic and $56.06 \%$ overweight). This study was approved by the Institutional Ethics Committee and informed consent was signed by participants and their parents or legal guardians.
Body mass index (BMI) was calculated as weight $(\mathrm{kg})$ divided by the square of height $(\mathrm{m})$. Age- and sex-specific BMI z-score and percentiles were calculated using CDC 2000 growth charts (Kuczmarski et al., 2002). Eutrophic was defined as a $<85$ percentile, overweight as a $\geq 85$ percentile, and obesity as $\geq 95$ percentile. The abdominal circumference $(A C)$ was measured in centimeters $(\mathrm{cm})$ at the level of the iliac crest. Thus, subjects were classified as eutrophic (percentile $<85$ ) and overweight/obese (percentile $\geq 85$ ) (Kuczmarski et al., 2002).

Blood samples were collected in the morning after 12 hours of fasting to perform measurements of glucose (Glu), triglycerides (TG), total cholesterol (TC), and high density lipoprotein cholesterol (HDL-C) by standard automated methods. Low density lipoprotein cholesterol (LDL-C) levels were calculated using the Friedewald equation (Friedewald et al., 1972), for TG levels below $200 \mathrm{mg} / \mathrm{dL}$.

\section{Genotyping assays}

DNA was extracted from peripheral blood by a salting-out method (Lahiri and Numberger, 1991) and was diluted to $20 \mathrm{ng} / \mu \mathrm{L}$. All SNPs were genotyped by TaqMan allelic discrimination assay on StepOnePlus real time PCR systems (Applied Biosystems, USA). Each reaction contained 3.0 $\mu \mathrm{L}$ of Master Mix (2X), $1.7 \mu \mathrm{L}$ of ultrapure water, $0.3 \mu \mathrm{L}$ of primer and $3.0 \mu \mathrm{L}$ of DNA. The reactions were performed according to the following protocol: 50 ${ }^{\circ} \mathrm{C}$ for $2 \mathrm{~min}, 95^{\circ} \mathrm{C}$ for $10 \mathrm{~min}$, and 50 cycles of $95^{\circ} \mathrm{C}$ for $15 \mathrm{~s}$ and $62^{\circ} \mathrm{C}$ for $1 \mathrm{~min}$.

\section{Statistical analysis}

Samples were classified into two groups, eutrophic and overweight (overweight + obese), categorized into above and below the median for age, AC, Glu, TC, LDL-C, HDL-C and TG levels. Chi-square tests were performed using Clump (Jakobsson and Rosenberg, 2007) to test for Hardy-Weinberg equilibrium and to compare allele proportions between groups above and below the median and also between eutrophic and overweight. Logistic regression analyses were performed to identify variables influencing serum glucose, lipid concentrations, and AC. False discovery rate (FDR) corrections (Benjamini and Hochberg, $1995)$ were performed for multiple testing. The significance level adopted was 0.05 (5\%).

\section{Results}

A descriptive analysis of the sample, displaying the variables considered in this study, is shown in Table 1. Significantly higher frequencies were found for the $\varepsilon 4$ allele in the group below the HDL-C median $(p=0.0001)$, and for the $\varepsilon 2$ allele in the group below the LDL-C median ( $p=0.0001$ ). Furthermore the $\varepsilon 3$ allele was associated with higher AC and excess weight $(p=0.0001)$. The allele frequencies are shown in Table 2. Logistic regression analysis was done using stratified TC as below and above the median as the de- 
Table 1 - Descriptive statistics for age, lipid profile, glucose, and abdominal circumference of the 393 individuals analyzed in this study.

\begin{tabular}{|c|c|c|c|c|c|c|c|}
\hline Variable* & $\mathrm{N}^{* *}$ & Mean \pm SE & Median & Variance & SD & Boys mean $\pm \mathrm{SE}$ & Girls mean $\pm \mathrm{SE}$ \\
\hline Age & 393 & $13.54 \pm 0.095$ & 13.96 & 3.56 & 1.89 & $13.54 \pm 0.12$ & $13.54 \pm 0.17$ \\
\hline HDL-C (mg/dL) & 369 & $47.59 \pm 0.89$ & 46.00 & 116.203 & 10.78 & $45.44 \pm 0.63$ & $51.69 \pm 1.02$ \\
\hline LDL-C (mg/dL) & 262 & $91.36 \pm 1.85$ & 87.50 & 898.187 & 29.97 & $89.93 \pm 2.53$ & $92.94 \pm 2.72$ \\
\hline $\mathrm{TG}(\mathrm{mg} / \mathrm{dL})$ & 367 & $99.17 \pm 2.88$ & 81.74 & 3055.92 & 55.28 & $96.06 \pm 3.35$ & $105.05 \pm 5.41$ \\
\hline $\mathrm{TC}(\mathrm{mg} / \mathrm{dL})$ & 262 & $162.67 \pm 2.19$ & 158.095 & 1261.96 & 35.52 & $160.42 \pm 2.98$ & $165.19 \pm 3.24$ \\
\hline Glu (mg/dL) & 387 & $89.50 \pm 0.56$ & 89.00 & 120.842 & 10.99 & $90.60 \pm 0.72$ & $87.25 \pm 0.83$ \\
\hline $\mathrm{AC}(\mathrm{cm})$ & 291 & $83.69 \pm 1.07$ & 81.50 & 333.001 & 18.25 & $80.77 \pm 1.21$ & $92.25 \pm 1.94$ \\
\hline
\end{tabular}

* High Density Lipoprotein Cholesterol (HDL-C), Low Density Lipoprotein Cholesterol (LDL-C), Triglycerides (TG), Total Cholesterol (TC), Glucose (Glu), Abdominal Circumference (AC).

**393 individuals were analyzed.

pendent variable, and for the polymorphisms analyzed (dominant model for $A P O E$ gene, in which $\varepsilon 4$ is dominant over $\varepsilon 2$; for the other polymorphisms, dominant, recessive, and additive models were tested), gender, AG, and anthropometric classification as independent variables. The same logistic regression analysis design was performed using LDL-C, HDL-C, TG, glucose, and AC as the dependent variable and maintaining the same independent variables. We identified the $A P O E$ gene $\varepsilon 4$ allele as a contributing factor in reducing HDL-C levels $(\beta=-0.29 \pm 0.08$, $p=0.015$ ) and the $\varepsilon 3$ allele as a risk factor for higher $\mathrm{AC}$ measures $(\beta=-0.24 \pm 0.08, p=0.041)$. We also found that obesity and overweight are independent risk factors for higher triglyceride levels $(\beta=0.30 \pm 0.08, p=0.021)$.
Furthermore, we observed that the A allele (rs846910) of the HSD11ß1 gene was associated with excessive weight ( $p=0.039$, Chi-square test). It is known that there is variation in metabolic processes inherent to gender, so we conducted the same analyses separately for each gender. We observed that in girls the alleles $\varepsilon 2$ and $\varepsilon 4$ of the $A P O E$ gene were associated with LDL-C below the median ( $p=0.0001$ by Chi-square test) and HDL-C below the median, independently of the other analyzed variables $(\beta=$ $-0.34 \pm 0.08, p=0.0039$ ) (Table 3). Furthermore, eutrophic girls had lower mean TG levels than obese or overweight girls $(\beta=0.30 \pm 0.08, p=0.0039)$. Regarding boys, we observed that the $\varepsilon 2$ allele is associated to lower LDL-C levels ( $p=0.019$ by Chi-square test) (Table 3 ).-

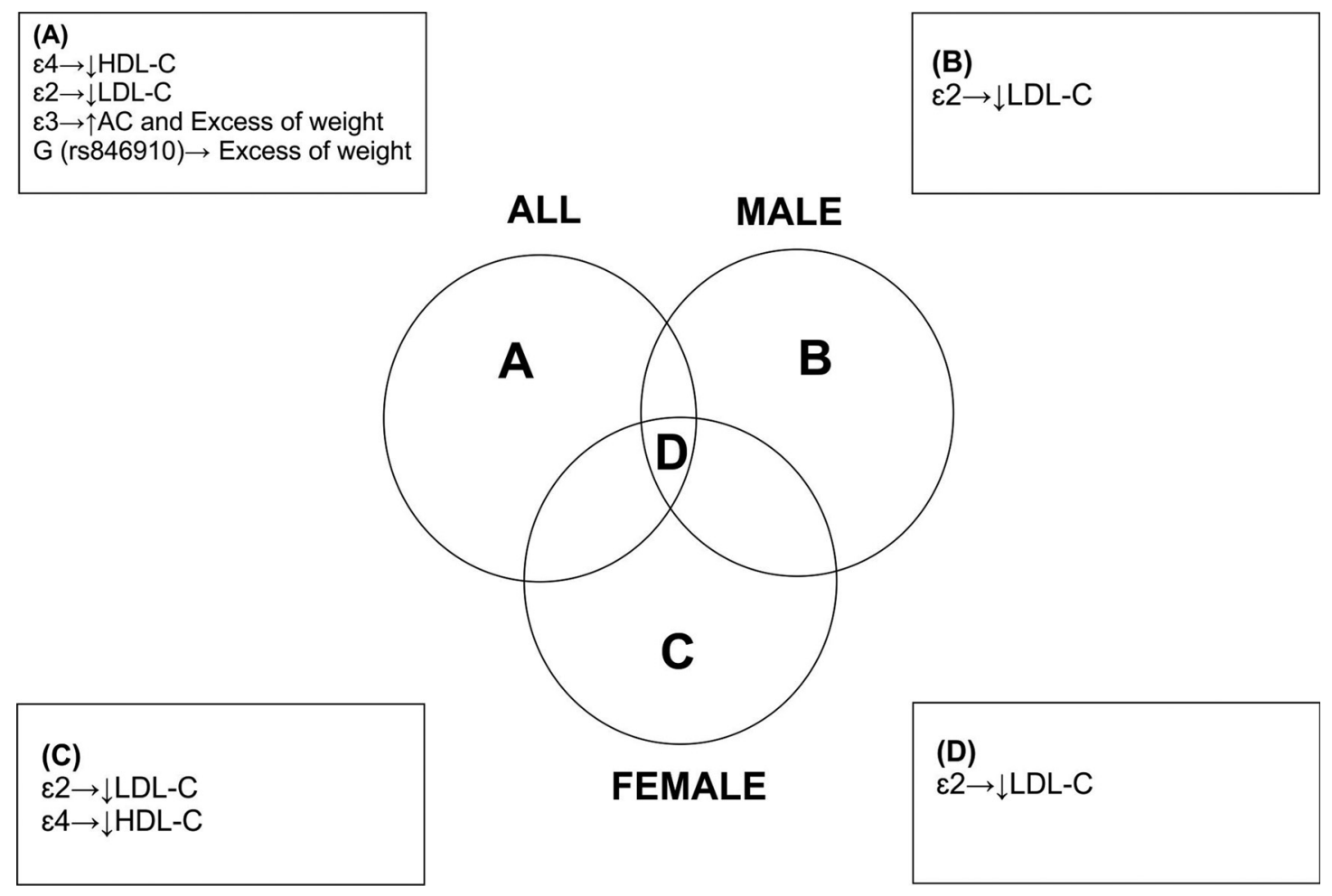

Figure 1 - Relationships between allelic variants and analyzed variables. 


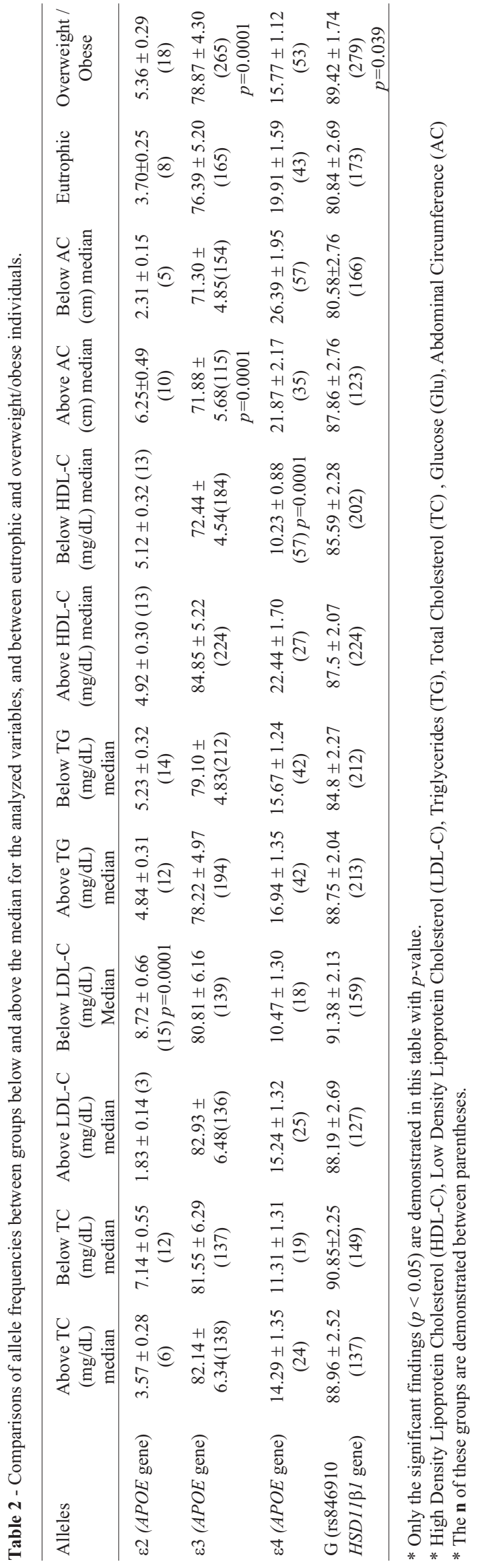

\section{Discussion}

Blood lipid levels are influenced by environmental and genetic factors (Crook, 2012), and it is known that LDL-C is the primary target for reducing cardiovascular risk (Catapano et al., 2016). In our study, as shown in Figure 1, it was observed that the $A P O E \varepsilon 2$ allele was associated with lower LDL-C levels in the total sample, as well as in girls and boys, which is consistent with the known protective effect of this allele (Frikke-Schmidt et al., 2000; Bennet et al., 2007; Fuzikawa et al., 2008; Ward et al., 2009; Nascimento et al., 2009; Bazzaz et al., 2010; Ferreira et al., 2010). Our finding is particularly relevant considering that the protective effect of the $\varepsilon 2$ allele is usually observed in adults, but in our study we observed that it is also present in children and adolescents, and therefore can contribute to lower LDL-C levels early in life.

The APOE- 84 allele seems to be associated with lower HDL-C levels, which support the notion that the $\varepsilon 4$ allele is an atherogenic risk factor (Frikke-Schmidt et al., 2000; Bennet et al., 2007; Fuzikawa et al., 2008; Ward et al., 2009). Being related to lower HDL-C levels, responsible for cholesterol reverse transport, this allele could contribute to higher cholesterol levels, and this is especially worrisome in children, considering all possible and severe comorbidity (ANVISA, 2011; Maria et al., 2011; Crook, 2012).

Besides its association with the lipid profile, some studies have demonstrated that the APOE gene influences characteristics of obesity (Volcik et al., 2006; TabatabaeiMalazy et al., 2012). According to the Atherosclerosis Risk in Communities (ARIC) study, the apo E genotypes were associated with BMI following the order: apo E4 > apo E3 $>$ apo E2 (Volcik et al., 2006). Srinivasan et al. (1994), who analyzed a sample of children and adolescents, similar to this study, found that the apo E3 group showed significant associations with obesity measures and lipoprotein variables.

Our work is in agreement with Sun et al. (2016) who also found some increased variables, such as BMI and LDL-C, in $\varepsilon 3$ allele carriers when compared to $\varepsilon 2$ allele carriers in the non-metabolic syndrome group (Sun et al., 2016). Some studies also have associated the $\varepsilon 4$ allele with features related to obesity in different populations (Tabatabaei-Malazy et al., 2012; Alharbi et al., 2017). Therefore, these polymorphisms in the APOE gene influence both lipid profile and traits related to obesity. It is important to highlight the relevance of studies involving this gene, especially in the young. We found a relationship between the $\mathrm{G}$ allele of the HSD11 11 gene rs846910 polymorphism and higher AC measurements. Some studies have demonstrated different effects of this polymorphism on serum lipid levels and other associated characteristics (Nair et al., 2004; Duran-Gonzalez et al., 2011; Dujic et al., 2012). Different from this study, Durán-Gonzalez et al. (2011) observed an association between the A allele and higher triglyceride 


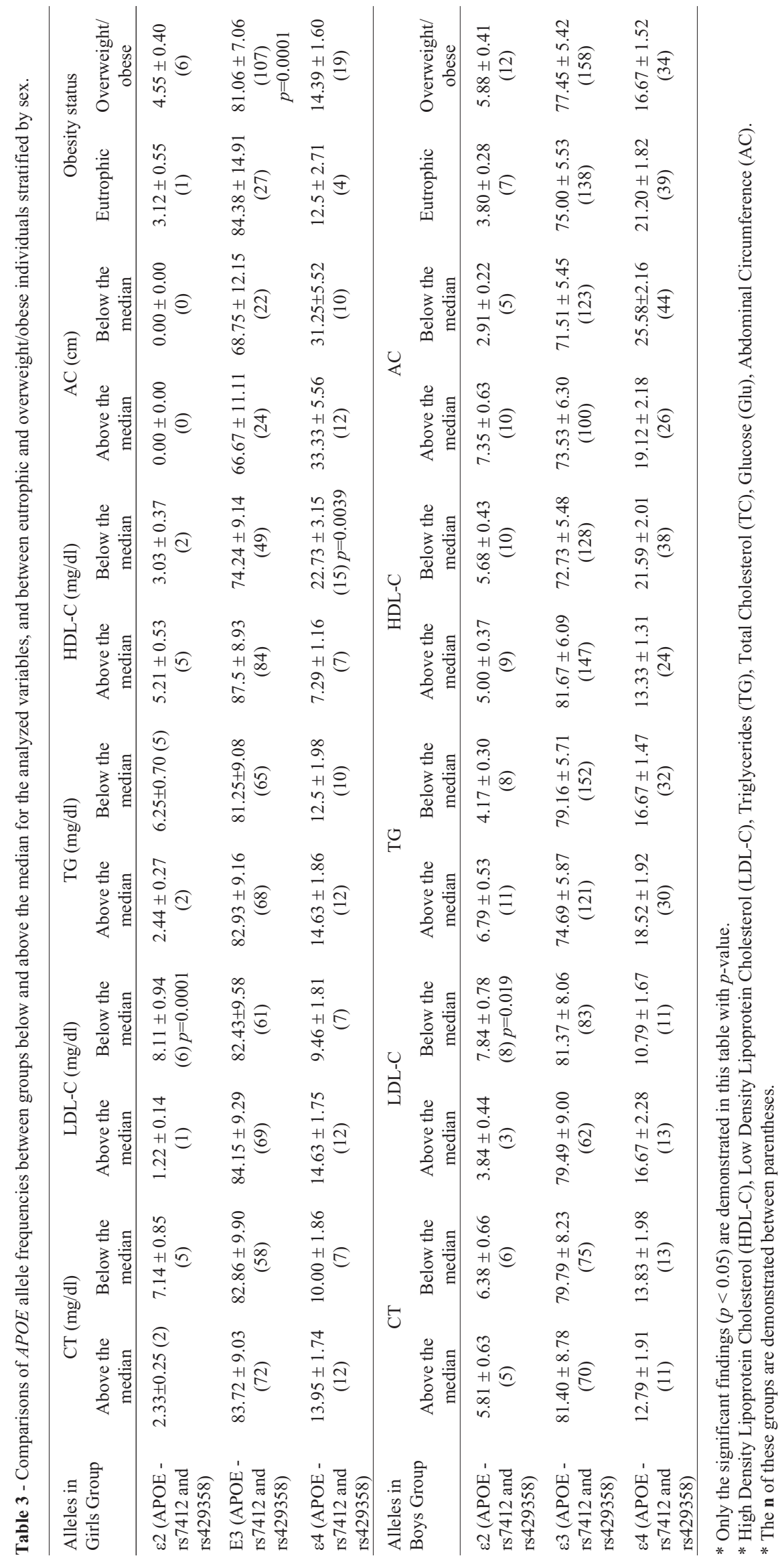


levels, and according to some studies this polymorphism could be associated to metabolic syndrome (Nair et al., 2004; Duran-Gonzalez et al., 2011; Dujic et al., 2012). However, Turek et al. (2014) found that the A allele ws associated with higher HDL-C levels only in women. Furthermore, it is relevant to consider that a possible linkage disequilibrium might exist with another polymorphism in the HSD11 1 1 gene, and another allele could be the cause of an altered lipid profile or features related to obesity (Malavasi et al., 2010).

Although our study had relevant findings, we recognize that the small sample size is a limitation, thus generalizability should be done with caution, and studies with larger samples should be done. In summary, we found that in children and adolescents, as in adults, the $\varepsilon 4$ and $\varepsilon 3$ alleles could be considered a contributing factor for dyslipidemia and traits related to obesity, respectively, while the $\varepsilon 2$ allele seems to be a protective factor, contributing to lower LDL-C and higher HDL-C levels. Furthermore, the $H S D 11 \beta 1$ gene $\mathrm{G}$ allele seems to be related to obesity. Considering that effects may start early in life, a precocious intervention could be planned, therefore preventing many complications resulting from altered lipid profile and obesity.

\section{Acknowledgments}

This work was financially supported by CAPES (Coordenação de Aperfeiçoamento de Pessoal de Nível Superior). The third author was supported by a research fellowship from CNPq (Conselho Nacional de Desenvolvimento Tecnológico e Científico).

\section{References}

Alcântara Neto OD, Silva RCR, Assis AMO and Pinto EJ (2012) Fatores associados à dislipidemia em crianças e adolescentes de escolas públicas de Salvador, Bahia. Rev Bras Epidemiol 15:335-345.

Alharbi KK, Syed R, Alharbi FK and Khan IA (2017) Association of Apolipoprotein E polymorphism with impact on overweight university pupils. Genet Test Mol Biomarkers 21:53-57.

ANVISA (2011) Dislipidemia. Saúde Econ 3:1-4.

Arita Y, Kihara S, Ouchi N, Takahashi M, Maeda K, Miyagawa J, Hotta K, Shimomura I, Nakamura T, Miyaoka K et al. (1999) Paradoxical decrease of an adipose-specific protein, adiponectin, in obesity. Biochem Biophys Res Commun 257:79-83.

Bazzaz JT, Nazari M, Nazem H, Amiri P, Fakhrzadeh H, Heshmat R, Abbaszadeh S and Amoli MM (2010) Apolipoprotein e gene polymorphism and total serum cholesterol level in Iranian population. J Postgrad Med 56:173-175.

Benjamini Y and Hochberg Y (1995) Controlling the false discovery rate: A pratical and powerful approach to multiple testing. J R Stat Soc 57:289-300.

Bennet AM, Di Angelantonio E, Ye Z, Wensley F, Dahlin A, Ahlbom A, Keavney B, Collins R, Wiman B, Faire U et al.
(2007) Association of apolipoprotein E genotypes with lipid levels and coronary risk. JAMA 298:1300-1311.

Blackhart BD, Ludwig EM, Pierotti VR, Caiati L, Onasch MA, Wallis SC, Powell L, Pease R, Knott TJ and Chu ML (1986) Structure of the human apolipoprotein B gene. J Biol Chem 261:15364-15367.

Brasaemle DL (2007) The perilipin family of structural lipid droplet proteins: Stabilization of lipid droplets and control of lipolysis. J Lipid Res 48:2547-2559.

Bujalska IJ, Kumar S and Stewart PM (1997) Does central obesity reflect "Cushing"s disease of the omentum? Lancet 349:1210-1213.

Catapano AL, Graham I, De Backer G, Wiklund O, Chapman MJ, Drexel H, Hoes AW, Jennings CS, Landmesser U, Pedersen TR et al. (2016) 2016 ESC/EAS guidelines for the management of dyslipidaemias. Eur Heart J 37:2999-3058.

Crook MA (2012) Plasma lipids and lipoproteins. In: Clinical Biochemistry and Metabolic Medicine. Hodder Arnold, London, pp 200-215.

Dujic T, Bego T, Mlinar B, Semiz S, Malenica M, Prnjavorac B, Ostanek B, Marc J and Causevic A (2012) Association between 11 beta-hydroxysteroid dehydrogenase type 1 gene polymorphisms and metabolic syndrome in Bosnian population. Biochem Medica 22:76-85.

Duran-Gonzalez J, Ortiz I, Gonzales E, Ruiz N, Ortiz M, Gonzalez A, Sanchez EK, Curet E, Fisher-Hoch S, Rentfro A et al. (2011) Association study of candidate gene polymorphisms and obesity in a young Mexican-American population from South Texas. Arch Med Res 42:523-531.

Ferreira CN, Carvalho MG, Fernandes APSM, Lima LM, Loures-Valle AA, Dantas J, Janka Z, Palotás A and Sousa MO (2010) Comparative study of apolipoprotein-E polymorphism and plasma lipid levels in dyslipidemic and asymptomatic subjects, and their implication in cardio/cerebro-vascular disorders. Neurochem Int 56:177-182.

Foley SM (2005) Update on risk factors for atherosclerosis: the role of inflammation and apolipoprotein E. Medsurg Nurs 14:43-50.

Friedewald WT, Levy RI and Fredrickson DS (1972) Estimation of the concentration of low-density lipoprotein cholesterol in plasma, without use of the preparative ultracentrifuge. Clin Chem 18:499-502.

Frikke-Schmidt R, Nordestgaard BG, Agerholm-Larsen B, Schnohr P and Tybjaerg-Hansen A (2000) Context-dependent and invariant associations between lipids, lipoproteins, and apolipoproteins and apolipoprotein E genotype. J Lipid Res 41:1812-1822.

Fuzikawa AK, Peixoto SV, Taufer M, Moriguchi EH and LimaCosta MF (2008) Association of ApoE polymorphisms with prevalent hypertension in 1406 older adults: The Bambuí Health Aging Study (BHAS). Braz J Med Biol Res 41:89-94.

Gambineri A, Tomassoni F, Munarini A, Stimson RH, Mioni R, Pagotto U, Chapman KE, Andrew R, Mantovani V, Pasquali $\mathrm{R}$ et al. (2011) A combination of polymorphisms in HSD11B1 associates with in vivo 11 beta\}-HSD1 activity and metabolic syndrome in women with and without polycystic ovary syndrome. Eur J Endocrinol 165:283-92.

Greenow K, Pearce NJ and Ramji DP (2005) The key role of Apolipoprotein $\mathrm{E}$ in atherosclerosis. $\mathrm{J}$ Mol Med 83:329-342. 
Heeren J, Beisiegel U and Grewal T (2006) Apolipoprotein E recycling: Implications for dyslipidemia and atherosclerosis. Arterioscler Thromb Vasc Biol 26:442-448.

Innerarity TL, Weisgraber KH, Arnold KS, Mahley RW, Krauss RM, Vega GL and Grundy SM (1987) Familial defective apolipoprotein B-100: Low density lipoproteins with abnormal receptor binding. Proc Natl Acad Sci USA 84:6919-6923.

Jakobsson M and Rosenberg NA (2007) CLUMPP: A cluster matching and permutation program for dealing with label switching and multimodality in analysis of population structure. Bioinformatics 23:1801-1806.

Kuczmarski RJ, Ogden CL, Guo SS, Grummer-Strawn LM, Flegal KM, Mei Z, Wei R, Curtin LR, Roche AF and Johnson CL (2002) 2000 CDC growth charts for the United States: Methods and development. Vital Health Stat 246:1-190

Lahiri DK and Numberger JI (1991) A rapid non-enzymatic method for the preparation of HMW DNA from blood for RFLP studies. Nucleic Acids Res 19:5444.

Lara-Castro C, Fu Y, Chung BH and Garvey WT (2007) Adiponectin and the metabolic syndrome: Mechanisms mediating risk for metabolic and cardiovascular disease. Curr Opin Lipidol 18:263-270.

Maeda K, Okubo K, Shimomura I, Funahashi T, Matsuzawa Y and Matsubara K (1996) cDNA cloning and expression of a novel adipose specific collagen-like factor, apM1 (AdiPose Most abundant Gene transcript 1). Biochem Biophys Res Commun 221:286-289.

Mahley RW (1988) Apolipoprotein E: Cholesterol transport protein with expanding role in cell biology. Science 240:622-630.

Malavasi ELV, Kelly V, Nath N, Gambineri A, Dakin RS, Pagotto U, Pasquali R, Walker BR and Chapman KE (2010) Functional effects of polymorphisms in the human gene encoding

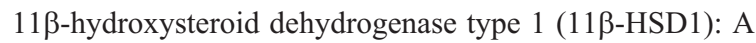
sequence variant at the translation start of $11 \beta$-HSD1 alters enzyme levels. Endocrinology 151:195-202.

Maria V, Polachini BV, Zanardo-Giovana S and Ceni C (2011) Avaliação do perfil lipídico dos pacientes com dislipidemia atendidos no ambulatório de especialidades de nutrição da URICEPP. Perspectiva (Erechim) 129:177-188.

Masuzaki H, Paterson J, Shinyama H, Morton NM, Mullins JJ, Seckl JR and Flier JS (2001) A transgenic model of visceral obesity and the metabolic syndrome. Science 294:2166-2170.

Myant NB (1993) Familial defective apolipoprotein B-100: A review, including some comparisons with familial hypercholesterolaemia. Atherosclerosis 104:1-18.

Nair S, Lee YH, Lindsay RS, Walker BR, Tataranni PA, Bogardus C, Baier LJ and Permana PA (2004) 11beta-Hydroxysteroid dehydrogenase Type 1: Genetic polymorphisms are associated with Type 2 diabetes in Pima Indians independently of obesity and expression in adipocyte and muscle. Diabetologia 47:1088-1095.

Nascimento H, Silva L, Lourenço P, Weinfurterová R, Castro E, Rego C, Ferreira H, Guerra A, Quintanilha A, Santos-Silva A et al. (2009) Lipid profile in Portuguese obese children and adolescents: Interaction of Apolipoprotein E polymor- phism with adiponectin levels. Arch Pediatr Adolesc Med 163:1030-1036.

Poirier J (2005) Apolipoprotein E, cholesterol transport and synthesis in sporadic Alzheimer's disease. Neurobiol Aging $26: 355-361$

Richardson K, Louie-Gao Q, Arnett DK, Parnell LD, Lai CQ, Davalos A, Fox CS, Demissie S, Cupples LA, FernandezHernando C et al. (2011) The plin4 variant rs 8887 modulates obesity related phenotypes in humans through creation of a novel mir-522 seed site. PLoS One 6: e:17944.

Soria LF, Ludwig EH, Clarke HRG, Vegat GL, Grundyt SM and Mccarthy BJ (1989) Association between a specific apolipoprotein $\mathrm{B}$ mutation and familial defective apolipoprotein B-100 (genetic disease/cholesterol metabolism). Genetics 86:587-591.

Srinivasan SR, Ehnholm C, Wattigney WA and Berenson GS (1994) Relationship between obesity and serum lipoproteins in children with different apolipoprotein E phenotypes: The Bogalusa Heart Study. Metabolism 43:470-475.

Sun Y, Wei R, Yan D, Xu F, Zhang X, Zhang B, Yimiti D, LI H, Sun $\mathrm{H}, \mathrm{Hu} \mathrm{C}$ et al. (2016) Association between APOE polymorphism and metabolic syndrome in Uyghur ethnic men. BMJ Open 6:e010049.

Tabatabaei-Malazy O, Fakhrzadeh H, Qorbani M, Amiri P, Larijani B, Tavakkoly-Bazzaz J and Amoli MM (2012) Apolipoprotein $\mathrm{E}$ gene polymorphism and its effect on anthropometric measures in normoglycemic subjects and type 2 diabetes. J Diabetes Metab Disord 11:18.

Tóth PP, Potter D and Ming EE (2012) Prevalence of lipid abnormalities in the United States: The National Health and Nutrition Examination Survey 2003-2006. J Clin Lipidol 6:325-330.

Turek LV, Leite N, Souza RLR, Lima JK, Milano GE, Silva Timossi L, Osiecki ACV, Osiecki R and Alle LF (2014) Gender-dependent association of HSD11B1 single nucleotide polymorphisms with glucose and HDL-C levels. Genet Mol Biol 37:490-495.

Volcik KA, Barkley RA, Hutchinson RG, Mosley TH, Heiss G, Sharrett AR, Ballantyne CM and Boerwinkle E (2006) Apolipoprotein E polymorphisms predict Low Density Lipoprotein cholesterol levels and carotid artery wall thickness but not incident coronary heart disease in 12,491 ARIC study participants. Am J Epidemiol 164:342-348.

Ward H, Mitrou PN, Bowman R, Luben R, Wareham NJ, Khaw KT and Bingham S (2009) APOE genotype, lipids, and coronary heart disease risk: A prospective population study. Arch Intern Med 169:1424-1429.

Weisgraber KH, Rall SC and Mahley RW (1981) Human E apoprotein heterogeneity. Cysteine-arginine interchanges in the amino acid sequence of the apo-E isoforms. J Biol Chem 256:9077-9083.

World Health Organization - WHO (2016) Physical activity recommendations. World Health Organization, Genebra.

Associate Editor: Maria Rita Passos-Bueno

License information: This is an open-access article distributed under the terms of the Creative Commons Attribution License (type CC-BY), which permits unrestricted use, distribution and reproduction in any medium, provided the original article is properly cited. 